University of South Carolina

Scholar Commons

Faculty Publications

Political Science, Department of

Summer 1995

\title{
Attention to candidates and issues in newspaper coverage of 1992 presidential campaign
}

Gordon Mantler

David Whiteman

University of South Carolina - Columbia, whiteman@sc.edu

Follow this and additional works at: https://scholarcommons.sc.edu/poli_facpub

Part of the Political Science Commons

Publication Info

Published in Newspaper Research Journal, Volume 16, Issue 3, Summer 1995, pages 14-28.

Mantler, G. \& Whiteman, D. (1995). Attention to candidates and issues in newspaper coverage of 1992

presidential campaign. Newspaper Research Journal, 16(3), 14-28.

Copyright @ 1995 Newspaper Research Journal.

This Article is brought to you by the Political Science, Department of at Scholar Commons. It has been accepted for inclusion in Faculty Publications by an authorized administrator of Scholar Commons. For more information, please contact digres@mailbox.sc.edu. 


\section{Attention to candidates and issues in newspaper coverage of 1992 presidential campaign}

by Gordon Mantler \& David Whiteman

This study of six major newspapers found substantial differences in coverage, with George Bush getting significantly more coverage in four of the six.

$\mathbf{T}_{\mathrm{s}}$

he presidential campaign and election of 1992 turned out to be one of the more exciting contests for the Oval Office in modern American history. Full of drama and colorful personalities and issues, the campaign captivated Americans for months. The emergence of a strong third-party candidate in Texas billionaire Ross Perot, even after he dropped out of the race for three months before returning in October, provided voters and the media with plenty to talk about. The role played by talk shows,

Critics from both the right and left claimed the American mainstream media's coverage reflected a bias. such as Donohue and Larry King Live, and specialty networks, like MTV, was also key to the more hip 1992 campaign.

As in many previous campaigns, one of the major themes of the contest was the constant criticism the media received for its campaign coverage. Critics from both the right and left claimed the American mainstream media's coverage reflected a bias. After the election, even the Clinton transition team expressed surprise over the softballs the media had been throwing them since November.

Mantler is with the News in Greenville, South Carolina. Whiteman is associate professor of government and international studies at the University of South Carolina in Columbia. 
Mantler-Whiteman: Presidential campaign - 15

The high level of excitement and energy demonstrated in the 1992 campaign, plus its potential historical significance, makes the media's campaign coverage an excellent specimen for research into the question of bias. This study provides, through a content assessment of six national newspapers, a systematic analysis of the national print media's coverage of the 1992 presidential campaign. The research explores coverage of the three presidential candidates, focusing specifically on variation in attention to both candidates and issues.

\section{The search for bias}

The subject of media bias, of course, is not new to 1992. Politicians, especially in the 20th century, have placed blame on the media for what they see as unfair coverage of their actions. And for years, journalism and political science scholars have explored, through various methods, whether these charges have any merit. Charges of media bias have become even more pronounced since World War II with the emergence of television, forcing newspapers to compete with what many think is a more exciting, instantaneous news medium. Studies since the 1950s have addressed different aspects of bias in newspapers' election coverage. According to Sandra Moriarty and Mark Popovich, bias, or preferential treatment, can be evaluated in a number of ways. ${ }^{1}$ Some studies have looked at the amount of space allocated to coverage of each candidate, while others consider the articles' positions on the page or their positive, negative or neutral content. But the numerous studies from the past 40 years have not resulted in any definitive conclusions.

One basic approach has been to examine various characteristics of campaign coverage, primarily the amount and prominence of coverage, and to attempt to relate variation in coverage to partisan bias, particularly bias associated with a newspaper's endorsement of a candidate. According to Guido H. Stempel III, the most prominent figure in this line of research, no study as of 1960 suggested the basic problem in election coverage was specific partisan bias. ${ }^{2}$ In 1980, Robert Stevenson and Mark Greene reviewed the studies of bias and found little evidence of "large scale, systematic favoring of one political party or candidate over the other in the last two or three decades." ${ }^{3}$ Stempel's studies of the coverage by the prestige press seemed to reflect this each year he looked at it: 1960, 1964, 1968, 1980 and 1988. Beyond the equality of overall coverage, Stempel said there was some variation among each of the newspaper's handling of campaign news. This was illustrated by the amount of space devoted to the campaign on page one, coverage over different periods of time, and headline distribution. But there was no single trend or single statistic that could accurately describe their performance, other than to say the campaign coverage was roughly equal. Stempel's conclusions from the 1988 campaign were much the same: six of the 14 papers Stempel studied gave the Democrats more coverage, while the other eight gave the Republicans more. Excluding neutral content, 
Republicans had the edge in overall column inches, 51.3 percent to 48.7 percent. Overall campaign coverage also seemed to be up from 1980, but on the front page it was down by 10 percent. Total inches in 1988 were dwarfed, however, by the inches devoted to the 1960 presidential campaign $(75,818$ compared to 119,648).

Also relevant to a study of the 1992 election is Stempel's study of the effect of a third-party candidate, George Wallace, on the prestige press's election coverage. ${ }^{4}$ In general, "coverage by the other papers indicated he was, from a news standpoint, not being considered as a major candidate." ${ }^{5}$ Only four of 15 papers gave Wallace about as much space as Nixon and Humphrey, while the others gave him far less. Coverage of Wallace averaged 21.8 percent, ranging from 30.4 percent in the Louisville Courier-Journal to 17 percent in the Chicago Tribune.

Studies before 1960 had suggested a link between coverage and the newspaper's editorial stance, including those by Sidney Kobre of Florida newspapers in the 1952 campaign, Malcolm Klein and Nathan Maccoby of eight metropolitan newspapers also in 1952, and Robert Batlin of coverage in 1896 and 1952 San Francisco newspapers. ${ }^{6}$ Research by Philip Coffey on the 1974 general election in Colorado found "that Republican papers gave the Republicans more space while the independent papers gave the Democrats more space." ${ }^{17}$ Another study by G. Cleveland Wilhoit and Taik Sup Auh found "a significant relationship between newspaper endorsement of candidates and favorable opinion poll coverage about them." 8 Stempel's findings, when looking at the effect of editorial endorsements on a specific newspaper's coverage, do not agree with these results, nor do studies by Doris Graber of the 1968 presidential campaign and by Repass and Steven Chaffee of the 1964 contest. ${ }^{9}$ Jeff Merron and Gary Gaddy, studying a limited sample of newspaper coverage of 1984 Democratic vice-presidential candidate Geraldine Ferraro's personal finances and the two major party conventions, had mixed conclusions. ${ }^{10}$ They found that editorial endorsements did not affect the coverage of Ferraro's finances but may have in their accounts of the conventions, concluding that "if editorial perspective is an influence on news play, it doesn't appear to be a strong one."11

Because of such mixed conclusions by numerous studies on the subject, Stevenson and Greene suggested there should be a "reconsideration" of the concept of bias. ${ }^{12}$ The standard definition of bias, they said, was defined as "the systematic differential treatment of one candidate, one party, one side of an issue over an extended period of time. Bias is the failure to treat all voices in the marketplace of ideas equally." They argued this definition is flawed, and newspapers, in their attempt to be fair, may force equal coverage of two candidates and distort the real differences in the candidates and their campaigns and suggested using specific cases in discussing bias; contending that one problem with past studies has been the examinations of the papers were over relatively long periods of time, enabling papers to balance their overall coverage, even if specific issues might show tremendous inequalities. In a 
similar vein, Jeff Merron and Gary Gaddy emphasized the disagreement over a few major stories may be totally overlooked by the general agreement between newspapers in coverage of the large number of routine campaign events. ${ }^{13}$

Investigating variation of campaign issue coverage represents a second basic approach to exploring bias. As Maxwell McCombs and Donald Shaw argued, the press might not tell people how to think, but seems to tell them what to think about - readers "apparently learn in direct proportion to the emphasis placed on the campaign issues by the mass media." ${ }^{14}$ They also found "a very strong relationship between the emphasis placed on different campaign issues by the media and the judgments of voters as to the salience and importance of various campaign topics. ${ }^{15}$ In her analysis of newspaper issue coverage in the last month of the 1968, 1972, 1976 and 1980 presidential campaigns, Doris Graber found many consistencies in the coverage of issues and events, and no researchers have found significantly different results since. ${ }^{16}$ Graber found three major features of the coverage: (1) the media devoted most stories to campaign hoopla and the horse-race aspects of the contests; (2) information about issues was patchy because the candidates and their campaign officials addressed only issues which would not alienate the voters; and (3) newspeople focused selectively on controversial issues that lent themselves to exciting stories. ${ }^{17}$

Not only did Graber find general consistencies such as the ones mentioned above in the coverage of those presidential campaigns, but also patterns concerning more specific issue areas. Her studies showed campaign events received the most coverage of any single issue, except in 1968 when the Vietnam War dominated the campaign coverage since much of the election rode on the conditions in Vietnam. ${ }^{18}$ By the time of the race between Ronald Reagan and incumbent President Jimmy Carter, campaign events and hoopla took up 52 percent of the total campaign inches. Coverage of foreign affairs accounted for 30 percent of the coverage in 1968, but then declined each year, hitting a low of 5 percent in 1980. Overall social problems also decreased sharply in coverage from 1968 to 1980. Domestic politics stories remained relatively consistent throughout the years, ranging from 21 to 29 percent. Coverage of economic issues, such as unemployment, taxes or the deficit, was low, ranging from 7 percent to 13 percent. Graber concluded the media would prefer to feature the horse-race glamour of campaign development rather than write complex campaign stories that most of the audience would probably ignore. ${ }^{19}$

\section{Research design}

The purpose of this study is to examine variation in newspaper coverage of the 1992 campaign in light of previous studies, particularly those of Stempel and Graber. The analysis focused on two major aspects: variation in coverage of the candidates and variation in coverage of issues. Analysis of the coverage of the candidates included the distribution of total column inches, 
page one column inches, headlines, and attributions. Based on previous findings, the expectation was the newspapers would give relatively equal coverage to Clinton and Bush and significantly less coverage to Perot. Given that Perot was officially in the race for only a month, determining what equal coverage would be in his case was somewhat complicated. If Perot received exactly equal coverage during his official time in the race, a 40-40-20 distribution would be expected. ${ }^{20}$

Analysis of the coverage of issues incorporated six issue categories: character, economic, foreign policy and military, human interest, campaign and social issues. The results of previous studies would suggest that campaign events and hoopla, the horse-race aspect, and other fluff stories would be expected to receive by far the most coverage.

This study examined six newspapers included in Stempel's prestige press: the New York Times, the Chicago Tribune, the Washington Post, the Atlanta Constitution, the Wall Street Journal and the Los Angeles Times. ${ }^{21}$ This selection is roughly representative of the various regions of the United States (with three Eastern papers, one from the Midwest, one from the South and one from the West). These institutions are also readily used as models for smaller regional newspapers, who tend to mimic the front pages and overall coverage of the big boys. The database included all articles in the first, or $\mathbf{A}$, section of every fourth issue of each paper, from August 31 to November 3, which resulted in a sample of two-and-a-half constructed weeks for each newspaper. ${ }^{22}$ Items on the editorial and viewpoint pages were excluded, including unsigned editorials, syndicated columns, opinion pieces and letters to the editor. The two content analysis techniques used by Stempel were also used in this study: space measurement and headline classification. For articles appearing on page one, column inches on the front page were recorded separately, along with whether the article appeared above or below the fold. In addition, the number of attributions to the candidate or his campaign staff were also recorded. ${ }^{23}$

Each story was labeled as one of five content types: Clinton, Bush, Perot, Neutral, or Neutral without mentioning candidates. ${ }^{24}$ These were determined according to statement analysis and the number of attributions to each candidate and their staff appearing in the article. For example, a story with three attributions to Clinton and eight to Bush would be considered a Bush article. When articles had a relatively even amount of attributions, no more than a differential of two between at least two candidates, some further criteria had to be used. A statement analysis specifically considering the focus and type of the story then determined the content type. For example, if attributions came out to seven for Clinton, five for Bush and four for Perot in an article about the vice presidential debate, statement analysis would be used. Because the story dealt with an event all the candidates participated in and where a number of issues were discussed, the story was labeled Neutral. ${ }^{25}$

Categories for headline analysis were taken from Stempel's work. ${ }^{27}$ Numbers representing columns, point size and deck number were logged for 
every story's headline. They were then translated into Stempel's headline classifications of streamer, spread head, two-column head, major one-column head and minor one-column head. ${ }^{28} \mathrm{~A}$ streamer is a headline which stretches across the entire page, usually at the top, but not always. A spread is a headline anywhere from three to five columns wide. A two-column is self-explanatory. A major one-column is a headline of more than 30 points and is normally displayed in a strong position. A minor one-column is any other one-column headline, including headlines for briefs and graphics' titles.

For the issue analysis, the content of all articles was classified in 30 separate issue categories, organized under six major divisions: character issues, economic issues, foreign policy and military issues, human interest, campaign issues, and social issues. ${ }^{29}$ Each article could have multiple issues. For example, the main topic of a particular New York Times campaign article about Clinton is general character issues, but it also touches upon free trade and what Clinton's itinerary is for the next few days. Column inches were recorded separately for each of these issue categories. ${ }^{30}$ Ultimately, content analysis of each article included 14 variables: paper code, date, page number, page number article jumped to (if any), above or below the fold (if on page one), column, point size of headline, number of decks, total column inches, number of candidate attributions (to Clinton, Bush and Perot), type, and issue.

\section{Results}

Table 1: Distribution of campaign coverage, excluding neutral material, by newspaper

(adjusted percentages)

Wall St. Chicago N.Y.
Journal Tribune Times
Post Atlanta

$\begin{array}{lccccccc}\text { Bush } & 49.6 \%^{*} & 42.5 \%^{*} & 39.7 \%^{*} & 51.9 \%^{*} & 41.4 \% & 30.7 \%{ }^{*} & 42.2 \% \\ \text { Clinton } & 28.9^{\star} & 33.1^{\star} & 35.1^{\star} & 32.1^{\star} & 39.8 & 47.6^{\star} & 36.9 \\ \text { Perot } & 21.5 & 24.3 & 25.2 & 16.0 & 18.8 & 21.7 & 20.9 \\ \text { Total } & 100.0 & 99.9 & 100.0 & 100.0 & 100.0 & 100.0 & 100.0\end{array}$

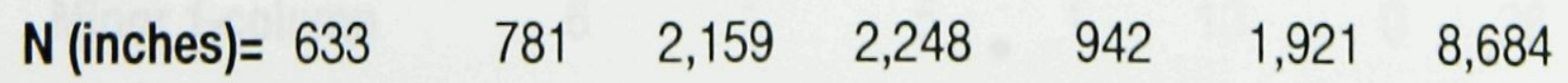




\section{Variation in coverage of candidates}

Table 1 displays the overall distribution of non-neutral coverage for each newspaper. ${ }^{31}$ When Stempel analyzed the prestige press in 1960, he found that 12 out of the 15 papers were within 5 percent of a 50-50 split in coverage. Results from 1992 coverage indicate that only two of the six newspapers (the Constitution and the New York Times) were within 5 percent of a 40-40 split between Clinton and Bush and that differences in the amount of coverage were statistically significant (at the .05 level) for five of the six papers. Coverage of Clinton ranged from a high of 47.6 percent in the L.A. Times to a low of 28.9 percent in the Journal, and the range of coverage for Bush was even greater - a high of 51.9 percent in the Post and a low of 30.7 percent in the L.A. Times. Only one newspaper, the L.A. Times, gave Clinton more coverage, while the rest gave Bush an advantage ranging from 1.6 to 20.7 percent. ${ }^{31}$ Expectations that endorsements would affect coverage received some support: the Tribune, the only paper to make an endorsement, provided Bush with a 9.4 percent advantage. Overall, however, the general equality of coverage found by Stempel and Graber does not seem to be evident in coverage of the 1992 campaign.

Past studies suggested that a third-party candidate usually receives little coverage compared to the Democrats and Republicans. In this case, Perot did have the lowest percentage of total inches in all six individual newspapers, but given that he was only officially in the presidential race for one of the two months included in this study, an equal proportion of coverage would be about 20 percent of the total coverage. Overall results indicate Perot received 20.9

Table 2: Distribution of page one coverage, excluding neutral material, by newspaper

(adjusted percentages)

\begin{tabular}{|c|c|c|c|c|c|c|c|}
\hline \multicolumn{8}{|c|}{ (adjusted percentages) } \\
\hline & $\begin{array}{l}\text { Wall St. } \\
\text { Journal }\end{array}$ & $\begin{array}{l}\text { Chicago } \\
\text { Tribune }\end{array}$ & $\begin{array}{l}\text { N.Y. } \\
\text { Times }\end{array}$ & $\begin{array}{l}\text { Wash. } \\
\text { Post }\end{array}$ & $\begin{array}{l}\text { Atlanta } \\
\text { Const. }\end{array}$ & $\begin{array}{l}\text { L.A. } \\
\text { Times }\end{array}$ & Overall \\
\hline Bush & $32.0 \%$ & $50.7 \%$ & $45.6 \%$ & $64.6 \%$ & $62.3 \%$ & $37.3 \%$ & $49.5 \%$ \\
\hline Clinton & 41.8 & 0.0 & 28.4 & 21.5 & 0.0 & 30.6 & 24.2 \\
\hline Perot & 26.2 & 49.3 & 26.0 & 13.9 & 37.6 & 32.1 & 26.3 \\
\hline Total & 100.0 & 100.0 & 100.0 & 100.0 & 99.9 & 100.0 & 100.0 \\
\hline $\mathbf{N}$ (inches) & $=233$ & 212 & 358 & 334 & 197 & 308 & 1,642 \\
\hline
\end{tabular}


Mantler-Whiteman: Presidential campaign - 21

percent, with more than 20 percent in four of the individual papers. This near equality of coverage far surpasses past study results on third-party candidates, such as Wallace in 1968 and John Anderson in 1980, and reflects in part the vast difference in the resources available to the Perot campaign compared to most third-party efforts.

The equality in page one inches which Stempel found was also not evident in this study, and in fact the disparities were even greater than for the total column inches. As shown in Table 2, Bush received 49.5 percent of the page one coverage, compared to 24.2 percent for Clinton and 26.3 percent for Perot. For two individual papers, the Post and the Constitution, Bush received more

Table 3: Headline distribution, by newspaper

Wall St. Chicago N.Y. Wash. Atlanta L.A. Overall Journal Tribune Times Post Const. Times

$\begin{array}{lrrrrrrr}\text { Bush } & 39 & 25 & 70 & 58 & 49 & 38 & 279 \\ \text { Streamer } & 0 & 6 & 1 & 5 & 2 & 1 & 15 \\ \text { Spread } & 1 & 6 & 18 & 19 & 10 & 16 & 70 \\ \text { 2-column } & 7 & 6 & 16 & 14 & 7 & 12 & 62 \\ \text { Major 1-column } & 7 & 4 & 9 & 4 & 1 & 5 & 30 \\ \text { Minor 1-column } & 24 & 3 & 26 & 16 & 29 & 4 & 102\end{array}$

\% more than 1-column $20.5 \% \quad 72.0 \% \quad 50.0 \% \quad 65.5 \% \quad 38.8 \% \quad 76.3 \% 52.7 \%$

$\begin{array}{lrrrrrrr}\text { Clinton } & 12 & 10 & 47 & 33 & 34 & 38 & 174 \\ \text { Streamer } & 0 & 0 & 1 & 2 & 2 & 2 & 7 \\ \text { Spread } & 1 & 6 & 6 & 13 & 8 & 16 & 50 \\ \text { 2-column } & 3 & 3 & 15 & 7 & 7 & 9 & 44 \\ \text { Major 1-column } & 1 & 1 & 7 & 0 & 0 & 6 & 15 \\ \text { Minor 1-column } & 7 & 0 & 18 & 11 & 17 & 5 & 58\end{array}$

\% more than 1-column $33.3 \% \quad 90.0 \% \quad 46.8 \% \quad 66.7 \% \quad 50.0 \% \quad 71.1 \% 58.1 \%$

$\begin{array}{lrrrrrrr}\text { Perot } & 8 & 7 & 27 & 15 & 21 & 13 & 91 \\ \text { Streamer } & 0 & 0 & 2 & 2 & 2 & 0 & 6 \\ \text { Spread } & 0 & 1 & 8 & 4 & 3 & 5 & 21 \\ \text { 2-column } & 2 & 5 & 8 & 4 & 3 & 4 & 26 \\ \text { Major 1-column } & 0 & 0 & 4 & 4 & 0 & 4 & 12 \\ \text { Minor 1-column } & 6 & 1 & 5 & 1 & 13 & 0 & 26\end{array}$

\% more than 1-column $25.0 \% \quad 85.7 \% \quad 66.7 \% \quad 66.7 \% \quad 38.1 \% \quad 69.2 \% 58.2 \%$ 
than 60 percent of the page one space. Even more surprising than Bush's dominance of page one space is Clinton's lack of it - even Perot beat out Clinton in overall coverage. Aside from the Journal, which gave Clinton 9.8 percent more page one coverage than Bush, the gap favoring Bush over Clinton ranged from 6.7 to 50.7 percent. Individual coverage of Perot on page one was extremely high for a third-party candidate, especially in the Tribune, where he received 49.3 percent of the page-one election coverage.

As shown in Table 3, the distribution of headlines revealed a relatively even distribution of headline sizes for the three campaigns. Despite Bush having more overall headlines, which directly reflected the amount of column inches devoted to each candidate, Clinton and Perot had a higher percentage of twocolumn or bigger heads than Bush. Both Clinton and Perot had a higher percentage of two-column plus headlines than Bush in four of the newspapers. There were a few instances of noticeable differences, such as the Tribune using six streamers for Bush stories but none for the other two candidates. But overall, those tended to be the exception rather than the rule. Overall, in regarding placement of headlines, there were no patterns of one candidate being grossly favored over a nother. The overall percentages of two-column or more headlines reflect this. ${ }^{32}$

Attributions provide another measure of the prominence of candidates in campaign coverage, and here the results were more equitable. While Bush received more column inches in every paper but the L.A. Times, Table 4 indicates that the Clinton campaign received the greater proportion of overall attributions: 42.3 percent, compared to 42.1 for Bush and 15.6 for Perot. The Tribune, the N.Y. Times and the L.A. Times quoted Clinton, Gore and their campaign staff more than the Republicans. Only in the Post and the Constitu-

Table 4: Attribution to each candidate, by newspaper

\begin{tabular}{|c|c|c|c|c|c|c|c|}
\hline \multicolumn{8}{|c|}{ (in percentages) } \\
\hline & $\begin{array}{l}\text { Wall St. } \\
\text { Journal }\end{array}$ & $\begin{array}{l}\text { Chicago } \\
\text { Tribune }\end{array}$ & $\begin{array}{l}\text { N.Y. } \\
\text { Times }\end{array}$ & $\begin{array}{l}\text { Wash. } \\
\text { Post }\end{array}$ & $\begin{array}{l}\text { Atlanta } \\
\text { Const. }\end{array}$ & $\begin{array}{l}\text { L.A. } \\
\text { Times }\end{array}$ & Overall \\
\hline Bush & $44.1 \%$ & $40.2 \%$ & $37.3 \%$ & $49.7 \%$ & $47.0 \%$ & $38.9 \%$ & $42.1 \%$ \\
\hline Clinton & 37.6 & 43.5 & 44.5 & 37.7 & 36.3 & 46.7 & 42.3 \\
\hline Perot & 18.3 & 16.3 & 18.2 & 12.6 & 16.7 & 14.4 & 15.6 \\
\hline Total & 100.0 & 100.0 & 100.0 & 100.0 & 100.0 & 100.0 & 100.0 \\
\hline $\mathbf{N}$ & 93 & 269 & 528 & 451 & 251 & 561 & 2,153 \\
\hline
\end{tabular}


tion did Bush have substantially more attributions, capturing 49.7 percent and 47 percent of the total number, respectively. Perot's overall attribution total was closer to the expectation for a third-party candidate than his column inch total, and across the newspapers his attribution rate was relatively consistent, ranging from 12.6 to 18.3 percent.

\section{Variation in coverage of issues}

The distribution of overall issue coverage, displayed in Table 5, reveals the expected prominence of horse-race stories and articles on campaign events and hoopla. The campaign issues category includes the general campaign itineraries, polls, debate negotiations, horse race stories, and candidate profile or style stories focusing on a certain trait of the candidate or his staff. The N.Y. Times

Table 5: Distribution of campaign coverage, by policy area, by newspaper

\begin{tabular}{|c|c|c|c|c|c|c|c|}
\hline \multicolumn{8}{|c|}{ (in percentages) } \\
\hline & $\begin{array}{l}\text { Wall St. } \\
\text { Journal }\end{array}$ & $\begin{array}{l}\text { Chicago } \\
\text { Tribune }\end{array}$ & $\begin{array}{l}\text { N.Y. } \\
\text { Times }\end{array}$ & $\begin{array}{l}\text { Wash. } \\
\text { Post }\end{array}$ & $\begin{array}{l}\text { Atlanta } \\
\text { Const. }\end{array}$ & $\begin{array}{l}\text { L.A. } \\
\text { Times }\end{array}$ & Overall \\
\hline $\begin{array}{l}\text { Character } \\
\text { issues }\end{array}$ & $1.3 \%$ & $10.0 \%$ & $8.3 \%$ & $10.0 \%$ & $9.4 \%$ & $11.0 \%$ & $9.1 \%$ \\
\hline $\begin{array}{l}\text { Economic } \\
\text { issues }\end{array}$ & 35.1 & 10.1 & 4.4 & 18.9 & 11.2 & 8.8 & 12.8 \\
\hline $\begin{array}{l}\text { Foreign } \\
\text { policy }\end{array}$ & 13.3 & 5.0 & 10.7 & 9.5 & 7.2 & 8.0 & 8.8 \\
\hline $\begin{array}{l}\text { Human } \\
\text { interest }\end{array}$ & 0.0 & 10.8 & 3.8 & 3.1 & 7.7 & 10.2 & 6.1 \\
\hline $\begin{array}{l}\text { Campaign } \\
\text { issues }\end{array}$ & 30.6 & 35.8 & 50.8 & 42.1 & 47.0 & 39.3 & 41.4 \\
\hline $\begin{array}{l}\text { Social } \\
\text { issues }\end{array}$ & 19.7 & 28.2 & 22.0 & 16.4 & 17.5 & 22.7 & 21.8 \\
\hline Total & 100.0 & 99.9 & 100.0 & 100.0 & 100.0 & 100.0 & 100.0 \\
\hline$N$ (inches)= & 1,595 & 2,152 & 3,596 & 3,851 & 2,186 & 4,135 & 17,515 \\
\hline
\end{tabular}


leads all papers with 50.8 percent devoted to this area, slightly less than the total of 52 percent Graber found in the last month of the Times coverage of the 1980 campaign. This means the Times spends less than half of its campaign coverage on issues related to the economy or foreign policy. ${ }^{33}$ Overall, the six papers devoted 41.4 percent of the coverage to campaign issues, a figure similar to Graber's in 1972. ${ }^{34}$ Not all papers were like the Times: The Journal and the Tribune spent 30.6 percent and 35.8 percent, respectively, on the campaign stories. For the Journal, campaign events took up less space than the economic issues category, 35.1 percent to 30.6 percent.

While the expectation that campaign events would dominate coverage was upheld for five of the six newspapers, coverage of other issues revealed substantial variation. Somewhat surprisingly, given past research, the six newspapers spent more space on economic issues than those examined in Graber's studies, but not by a large amount. Because of the year-long recession in 1992 and the effects of it, including higher unemployment, lower productivity and low consumer confidence, the economy did seem to be the largest single issue in the race for the presidency. And it was an issue which seemed to favor the Clinton/Gore ticket. According to Jim Carville, Clinton's campaign manager, the whole campaign focused on "The Economy, Stupid!" Economic issues, including taxes, the deficit, jobs and the general economy, received 12.8 percent of the overall coverage. The Journal, by far, gave the most space to economics, 35.1 percent, while the N.Y. Times spent the least, 4.4 percent.

Overall, the social issues category, which included the environment and education, received the second highest percentage of coverage ( 21.8 percent). For foreign policy, the trend of less and less coverage did not continue in 1992, although it is difficult to explain why papers in 1992 would increase coverage of foreign affairs, which was greatly overshadowed by the economy, compared to coverage in 1980 when foreign policy disasters, such as the Iranian hostage crisis, plagued Carter's reelection bid by making the United States appear weak. Overall coverage was 8.8 percent, with the Tribune devoting the smallest proportion of space (5 percent) and the Journal the largest. Two other categories used in this study do not correspond directly to ones used by Graber: character issues and human interest. Character was the cornerstone of President Bush's reelection bid. With a weak economy, the question of "Can you trust Bill Clinton?" was effective in winning some votes for the GOP ticket. With the exception of the Journal, the papers devoted around 10 percent of their overall coverage to trust and character, and specifically to the Clinton draft record and the Iran-Contra scandal from the Reagan administration.

\section{Discussion}

This study has attempted to contribute to the on-going discussion of bias in newspaper reporting. Overall findings indicate substantial differences in 
how newspapers covered the 1992 presidential campaign, both in coverage of candidates and coverage of issues. An important point to remember, made by Guido Stempel after completion of his original 1961 study, was that even though there were many patterns to be found in newspaper coverage, each newspaper also has its individuality, which comes out in its everyday work, including campaign coverage. It is quite difficult and misleading to lump all of the media or all newspapers or all television networks into one category. Many critics of the media fall into this trap of labeling most or all journalists biased. This happened in 1992, when conservatives thought Clinton was being favored by the liberal press.

But this study shows the individuality of six respected national newspapers and suggests much of the media displays at least some individual charac-

The Post, considered a
liberal-leaning paper,
surprisingly gave the
president a tremendous
amount of overall
coverage, especially on
page one, while devoting
only 32.1 percent of its
space to Clinton.
ter in their coverage. The Journal is probably the most distinctive of the six studied here. It is primarily a business newspaper, specifically targeting the business community. For that reason, it should not be surprising it emphasized economic issues (with almost double the proportion of coverage of the next highest paper) and paid little attention to campaign events, the horse-race aspect and human interest fluff. It gave much more space to the incumbent, but seemed to respect the Democratic challenger in giving him a little more space in the briefs on page one than Bush. The Journal also focused more on foreign policy than the rest, rejecting the idea that foreign affairs was a blasé issue in 1992.

The other five newspapers were also distinctive, but in more subtle ways. The Post, considered a liberal-leaning paper, surprisingly gave the president a tremendous amount of overall coverage, especially on page one, while devoting only 32.1 percent of its space to Clinton. It also only spent 16.4 percent on social issues, a small amount for a paper with its reputation. However, it had the second highest amount of space on economic issues, Clinton's strongest point. It also focused more on the Iran-Contra affair, a thorn in Bush's side, than any other paper, 4.8 percent. The Post also gave Perot the least amount of space with only 16 percent, possibly because the Post editors thought he should not be taken seriously.

The Tribune devoted relatively few column inches to the campaign, higher only than the Journal. Like the Journal, the Tribune was also low in campaign stories, but instead of emphasizing economic issues, its coverage included the highest proportion of coverage of social issues and a greater than average proportion of human interest stories. Even though it almost seemed isolationist in its virtual omission of foreign affairs, foreign policy was the fifth highest single issue. Much of its coverage also seemed fragmented; rather than 
spend an article on a campaign stop, which received a large amount of space in other papers, the Tribune would ignore it or brief it.

The approach taken in this research is certainly not the only legitimate method. As Stevenson and Greene pointed out, examining the overall coverage by a newspaper misses the coverage of individual events, which is where bias may lie. The other question they legitimately ask is: should the candidates be covered equally? In the case of the 1984 presidential campaign, President Ronald Reagan was the candidate who made the news, not Walter Mondale. Does that still mean the media should give totally equal coverage to the two candidates? And what type of coverage do third-party candidates deserve? What is perhaps most disturbing about the results of this study is the distribution of the coverage of issues: the horse-race and general campaign events and anecdotes take up most of the papers' coverage of the presidential campaign. The 1992 campaign was praised for its high concentration on the issues, but this was not obvious when looking at the newspapers' accounts day after day. Individuality of newspapers is fine, but the superficiality of the coverage is not.

\section{Notes}

1. Sandra Moriarty and Mark Popovich, Newsmagazine Visuals and the 1988 Presidential Election. Journalism Quarterly, Summer 1991, pp. 371-380.

2. Guido H. Stempel III, The Prestige Press Covers the 1960 Presidential Campaign. Journalism Quarterly, Spring1961, p. 157.

3. Robert Stevenson and Mark Greene, A Reconsideration of Bias in the News. Journalism Quarterly, Spring 1980, p. 115.

4. Guido H. Stempel III, The Prestige Press Meets the Third Party Challenge. Journalism Quarterly, Winter 1969, pp. 699-706.

5. Ibid., p. 706.

6. Sidney Kobre, How Florida Dailies Handled the 1952 Presidential Campaign. Journalism Quarterly, Spring 1953, pp.163-169. Malcolm Klein and Nathan Maccoby, Newspaper Objectivity in the 1952 Campaign. Journalism Quarterly, Summer 1954, pp. 285296. Robert Batlin, San Francisco Newspapers' Campaign Coverage: 1896-1952. Journalism Quarterly, Summer 1954, pp. 297-303.

7. Philip Coffey, A Quantitative Measure of Bias in Reporting of Political News. Journalism Quarterly, Fall 1975, p. 522.

8. G. Cleveland Wilhoit and Taik Sup Auh, Newspaper Endorsement and Coverage of Public Opinion Polls in 1970. Journalism Quarterly, Winter 1974, p. 657.

9. Stempel, op. cit. ,1961, p. 159. Guido H. Stempel III and John Windhauser, Coverage by the Prestige Press of the 1988 Presidential Campaign. Journalism Quarterly, Winter1989, p. 895. Doris Graber, Press Coverage Patterns of Campaign News: the 1968 Presidential Race. Journalism Quarterly, Fall 1971, p. 508.

10. Jeff Merron and Gary Gaddy, Editorial Endorsements and News Play Bias in Coverage of Ferraro's Finances. Journalism Quarterly, Spring 1986, pp.127-137.

11. Ibid., p. 135. 
12. Stevenson and Greene, op. cit., p. 115.

13. Merron and Gaddy, op. cit., p. 128.

14. Maxwell McCombs and Donald Shaw, The Agenda-Setting Function of the Mass Media. Public Opinion Quarterly, Summer 1972, p. 177.

15. Ibid., p. 181.

16. Doris Graber, Mass Media and American Politics. Washington: Congressional Quarterly Press 1989, p. 200.

17. Ibid., p. 216.

18. Ibid., p. 217.

19. Ibid.

20. The 40-40-20 distribution is derived from the relative involvement of the three candidates in the campaign: Clinton and Bush actively campaigned during the roughly two months examined in this study, while Perot only actively campaigned for one month. If coverage throughout the two months was completely equal, then, Clinton and Bush would each receive 40 percent of it and Perot 20 percent of it.

21. In his original studies, Stempel examined coverage in every issue between Labor Day and the eve of Election Day for 15 newspapers. The newspapers he used were dubbed the prestige press according to a poll of editors published in Editor \& Publisher and were considered the "most superior for news coverage, integrity and public service." $\mathrm{He}$ continued to use these papers in his studies of 1964 and 1968 campaign coverage. However, his studies in 1980 and 1988 used one less paper, because the Chicago Daily News had stopped publishing.

22. Analysis began before Labor Day in order to include coverage from November 2, the day before the election. Only 13 issues of the Wall Street Journal were studied since it does not publish on weekends.

23. Attributions refer to any statement, either a quote or paraphrase, which is attributed to the candidate, his running-mate, or the campaign's officials. For instance, if an article had three quotes from Bush, one from Quayle and two from Bush/Quayle spokeswoman Mary Matalin, six attributions would be recorded under Bush.

24. Stempel used a similar categorization system; he divided stories into categories for each of the candidates plus a neutral group. This study added one more category-"neutral without mentioning candidates" - to aid in the issue analysis segment of the research.

25. A story where only two candidates were mentioned prominently could still be considered neutral. An article with the same attribution totals, but exclusively about Clinton's draft record, would be labeled Clinton. However, there were very few articles with these extreme characteristics. Most articles had either a lopsided ratio of attributions or attributions from just one candidate. Because of this, the somewhat simpler either-or coding system used was adequate.

26. Stempel, op. cit.,1961, p. 159. "These distinctions are indicative of real differences in news value in the opinion of the editor when he selects a particular size headline for a story." These methods are largely a replication of Stempel's past studies, with some variation. Changes included separate data recorded for above and below the fold of page one, and an expansion of categories in which to place articles, including stories focused primarily on the third-party candidate and neutral issues. What determined the classification of articles not only included a statement analysis but also a count of attributions given to each candidate in the article. The minimum point size for a major one-column 
headline was also changed from 24 in the original Stempel study to 30 points in this one. 27. Ibid.

28. The six main divisions are largely self-explanatory. The campaign issues category included coverage of the candidates' campaign itinerary, campaign events, strategies, political advertisements (such as the fairness and accuracy of specific advertisements in the Pos's 30 Seconds column), and campaign trail anecdotes. Also included were the horse-race stories, which appeared with increasing frequency near the end of the campaign.

29. For the purpose of this study, the six major divisions provide the necessary data to draw conclusions as to the general themes newspapers focused on in their coverage. An individual newspaper's coverage of a specific issue, such as Iran-Contra or the deficit, is beyond this study's scope.

30. To focus on the variation in candidate coverage across the newspapers, it was most appropriate to disregard the neutral material (which comprised about 50 percent of the overall coverage) for certain parts of the research.

31. Because 1992 was a year when there was an incumbent president, one potential complication in coding was distinguishing between stories about "Bush as president" and those about "Bush as candidate." However, the Rose Garden strategy was not very visible in campaign coverage. This was in part because the tightness of the race kept Bush in the country for almost all of the two months studied and because Congress held only a short, relatively inactive session in September. This was also due to the way newspapers tended to cover presidential events, blurring the lines between the two roles and making most of these events very much a part of the campaign. For example, coverage of Bush's veto of the cable regulation bill was seen as a political event, focusing on how his veto of a widely popular bill, and the subsequent congressional override, would affect his poll numbers and overall support for re-election. Because of these factors, all stories about Bush were included in this analysis.

32. In his 1961 study, Stempel found the proportion of headlines for each side to be close to that of the total inches devoted to a candidate. But overall, there were "few instances of constant patterns in any direction" (Stempel, op.cit., 1961, p. 63).

33. It is important to note that, as in the rest of this study, the proportion of coverage, rather than absolute amount of coverage, is the yardstick used. Obviously, the New York Times would have more absolute coverage on all issues, but how the Times distributes that coverage is what is under examination.

34. One reason why Graber's totals on coverage of campaign events should be expected to be high is that her study was conducted in the last month of the campaign, rather than the whole two-month campaign from Labor Day to Election Day. As the content analysis for this study moved to articles written towards the end of the campaign, the increase in campaign events, especially horse-race articles, was noticeable. A statement from the N.Y. Times (October 30, 1992, p. A17) probably sums it up the best: "Campaigns take on a sameness in these final days, a numbing repetition of speeches and events." 
Copyright of Newspaper Research Journal is the property of Newspaper Research Journal. The copyright in an individual article may be maintained by the author in certain cases. Content may not be copied or emailed to multiple sites or posted to a listserv without the copyright holder's express written permission. However, users may print, download, or email articles for individual use. 